\title{
FIGO Stage IIIA1 Ovarian Cancer
}

National Cancer Institute

\section{Source}

National Cancer Institute. FlGO Stage IIIA1 Ovarian Cancer. NCI Thesaurus. Code C128088.

Ovarian cancer with positive retroperitoneal lymph nodes only. (FIGO, 2014) 